\title{
Eichhornia crassipes- A Menace to Fresh Water Bodies and Its Sustainable Ethanol Extraction: Mini Review
}

\author{
Mansi Tripathi and Sunil Kumar Singal* \\ Department of civil engineering, Indian Institute of Technology Roorkee, India
}

Submission: June 16, 2017, Published: July 03, 2017

*Corresponding author: Sunil Kumar Singal, Department of civil engineering, Maharaja Agrasen Institute of Technology, Noida, India, Email: sunilksingal@gmail.com

\section{Abstract}

Water Hyacinth is a menace to fresh water bodies in the tropics and causes serious treats to the water quality by affecting its ecology. This mini-review highlights the process of ethanol extraction from its biomass for use as an alternate fuel. Thus converting the bane to a boon. Keywords: Water hyacinth; Eichhornia crassipes; Water; Fermentation; Ethanol

\section{Introductions}

Water hyacinth (Eichhornia crassipes), is a free-floating aquatic macrophyte, and is also an invasive planta species found in several parts of the world. It often jams rivers and lakes with tons of floating plant matter [1] which leads to serious problems in navigation, irrigation, and power generation [2]. Under favourable weather conditions, a healthy acre of water hyacinth can weigh up to 200 tons and row to very high density of over $60 \mathrm{~kg} / \mathrm{m}^{2}$ [3]. Its stems and leaves contain unique aerenchymatous tissue which provides the plant its substantial upthrust; thus preventing the entry of sunlight into water, required for algae and other forms of life [4]. Doubling time of 6 to 18 days has also been reported for Water hyacinth under favourable circumstances [5]. With one of the highest doubling rates of any plant known, its population can double in as low as 12 days [6]. Eichhornia growth has been reported in temporary ponds, marshes and sluggish flowing waters to large lakes, rivers and reservoirs [2].

The reason for this tremendous growth rate is probably that, it can tolerate wide variation in nutrients, temperature and $\mathrm{pH}$ levels. The optimum $\mathrm{pH}$ for growth of water hyacinth is 6 to 8 and it can tolerate temperatures ranging from 10 to $40{ }^{\circ} \mathrm{C}[7,8]$.

\section{Discussion}

The process of conversion of Eichhornia biomass into fuel ethanol (bioethanol) involves the following steps [9].

\section{Preparation of water hyacinth}

summarizes the steps in preparation of Eichhornia for ethanol extraction (Figure 1).

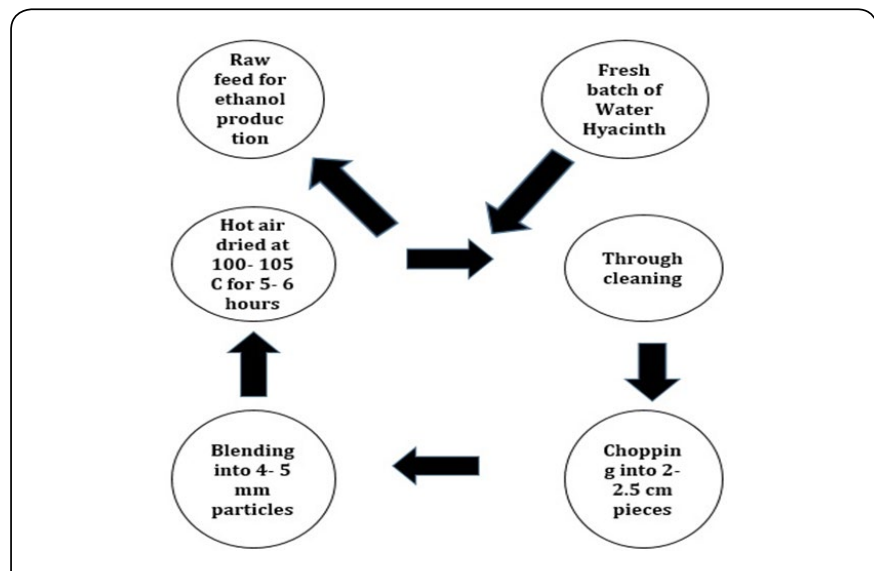

Figure 1: Some common abiotic stress factors that affect plants.

\section{Pretreatment}

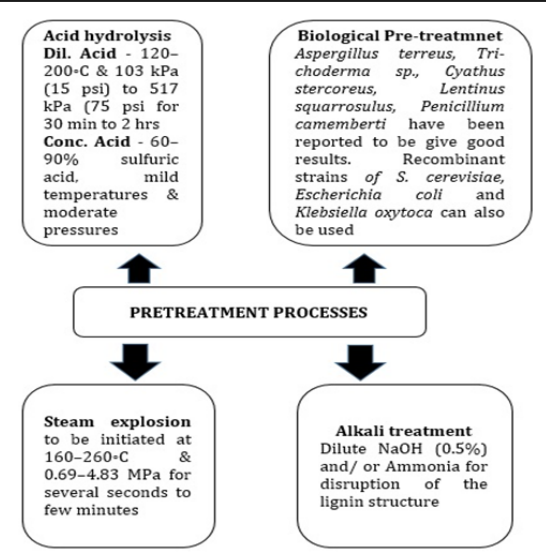

Figure 2: Pre-treatment steps of ethanol production [10]. 
Pretreatment of lignocellulosic materials is carried out to increase the surface area followed by breakdown into simpler sugars. Details of various types of methods are shown in (Figure 2).

\section{Cultivation and activation of microorganisms}

In the ethanol production process, the most efficient micro organism should be chosen after determination of the process type and equipment. The chosen microorganism should have the following characteristics-
A. High product yield
B. Tolerance for low $\mathrm{pH}$ values
C. Tolerance for temperature changes
D. Saturated ethanol tolerance

E. Ability to remain stable under fermentation conditions

Saccharomyces cerevisiae, Clostridium thermocellum Clostridium and Pichiastipites are some of the species commonly used [10-12].

\section{Fermentation}

Under anaerobic conditions, microorganisms use the substrate gained from lignocellulosic biomaterials of Water hyacinth. After the completion of the complete fermentation process, bioethanol is produced. Fermentation process occurs by the Embden-Meyerhof-Parnas (EMP) process and glycolytic pathway's enzymes.

\section{Distillation \& Dehydration}

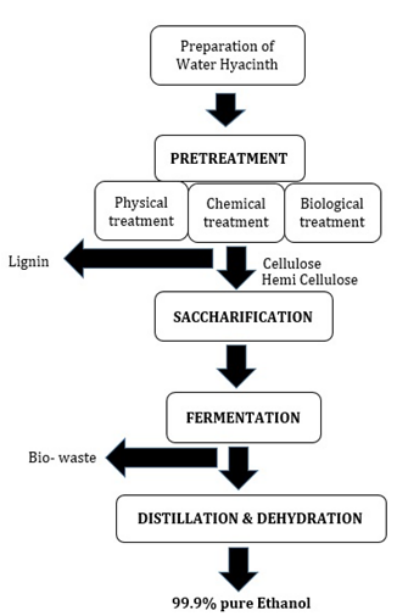

Figure 3: Complete process of ethanol extraction from Water Hyacinth [11].

Ethanol is obtained from the process medium before the last step in the distillation process. Ethanol can easily mix with water (azeotropic mixture) and is obtained by providing suitable conditions. As Ethanol's boiling point is $78.8^{\circ} \mathrm{C}$, it boils away. The distillation column is used to obtain $95 \%$ ethanol.
But this percentage is not useful to utilize the ethanol in vehicle engines, hence by using a water retaining column, it is easy to obtain $99.9 \%$ water-free ethanol, than can be used as a fuel in vehicles $[7,13]$. The entire process can be summarized as shown in (Figure 3).

\section{Conclusion}

Water Hyacinth is found in abundance across the tropics and has the potential of being put to several uses including extraction of ethanol for being utilized as a fuel. However, ethanol production from this feedstock still has several technical challenges including biomass collection and preprocessing. It has also been observed that decentralized plants prove to be more productive for ethanol production. Studies have also demonstrated that it is possible to achieve around $71 \%$ efficiency in saccharification step of ethanol production by using very crude and cost effective methods for pre-treatment and onsite enzyme production. At the same time, Usage of more suitable organisms for fermentation can also improve the yield of ethanol. Technically less intensive operations may be utilized such as employing non-skilled workers in order to reduce the production cost.

\section{References}

1. International Energy Agency (IEA) (2005) Biogas Production and Utilization. IEA Bio-Energy.

2. Gopal B (1987) Aquatic Plant Studies. [1 ${ }^{\text {st }}$ Edn.], Water Hyacinth, Oxford University, USA, p. 471.

3. Njogu P, Kinyua R, Muthoni P, Nemoto Y (2005) Biogas Production Using Water Hyacinth (Eichhornia crassipes) for Electricity Generation in Kenya. Energy and Power Engineering 7: 209-216.

4. Tiwari S, Dixit S, Verma N (2007) An effective means of biofiltration of heavy metal contaminated water bodies using aquatic weed Eichhorniacrassipes. Environ Monitor Assess 129(1-3): 253-256.

5. Verma R, Singh SP, Ganesha Raj K (2003) Assessment of changes in water hyacinth coverage of water bodies in northern part of Bangalore city using temporal remote sensing data. Curr Sci 84(6): 795-804.

6. Herfjord T, Osthagen H, Saelthun NR (1994) The water hyacinth. Norwegian Agency for Development Cooperation. Water Resources and Energy Administration, Oslo ISBN, 82(410): 206-207.

7. Sandip S, Sandeep M, More M, Nadaf AA (2012) Biochemical conversion of acid- pretreated water hyacinth (Eichhorniacrassipes) to alcohol using PichiaSti- pitis NCIM3497. Int J AdvBiotechnol Res 3(2): 585-590.

8. Rezania S, Ponraj M, Md Din MF, Songip AR, Sairan FM, et al. (2015) The diverse applications of water hyacinth with main focus on sustainable energy and production for new era: An overview. Renewable and Sustainable Energy Reviews 41: 943-954.

9. Clark TA, Mackie KL (1984) Fermentation inhibitors in wood hydrolysates derived from wood Pinusradiata. J Chem Technol Biotechnol 34(b): 101110.

10. Bayrakci AG, Koçar G (2014) Second-generation bioethanol production from water hyacinth and duckweed in Izmir: A case study. Renewable and Sustainable Energy Reviews 30: 306-316.

11. Ganguly A, Chatterjee PK, Dey A (2012) Studies on ethanol production from water hyacinth-A review. Renewable and Sustainable Energy Reviews 16: 966-972. 
12. Bayrakci AG (2009) An investigation on bioethanol production from different biomass resources [Master thesis] in Tukish: Ege University Solar Energy Institute, Solar Energy Institute, Turkey.
13. Aswathy US, Sukumaran RK, Lalitha Devi G, Rajasree KP, Singhania RR et al. (2010) Bio-ethanol from water hyacinth biomass: An evaluation of enzymatic saccharification strategy. Bioresource Technology 101: 925-930.

\author{
Your next submission with Juniper Publishers \\ will reach you the below assets \\ - Quality Editorial service \\ - Swift Peer Review \\ - Reprints availability \\ - E-prints Service \\ - Manuscript Podcast for convenient understanding \\ - Global attainment for your research \\ - Manuscript accessibility in different formats \\ ( Pdf, E-pub, Full Text, Audio) \\ - Unceasing customer service
}

Track the below URL for one-step submission https://juniperpublishers.com/online-submission.php 